\title{
PERSIDANGAN ELEKTRONIK (E-LITIGASI) PADA PERADILAN TATA USAHA NEGARA
}

\author{
Agus Salim, Elfran Bima Muttaqin \\ Universitas Kristen Indonesia Paulus, agus_salim@ukipaulus.ac.id
}

\begin{abstract}
Abstrak
Peradilan Tata Usaha Negara sebagai pelaksana kekuasaan kehakiman mempunyai tugas dan wewenang untuk memeriksa, memutus, dan menyelesaikan sengketa Tata Usaha Negara (TUN). Seiring dengan perkembangan kemajuan teknologi, praktik peradilan dalam lingkup Mahkamah Agung RI mengimplementasikan penggunaan aplikasi e-court Mahkamah Agung RI. Tujuan penelitian ini adalah untuk menganalisis kebijakan mengenai pelaksanaan E-Litigasi pada Peradilan Tata Usaha Negara, sekaligus menemukan kendala yang dihadapi. Penelitian ini menggunakan metode yuridis normatif dengan pendekatan perundang-undangan, yaitu Undang-Undang Nomor 5 Tahun 1986 tentang Peradilan Tata Usaha Negara serta perubahan-perubahannya dan Peraturan Mahkamah Agung Nomor 1 Tahun 2019 tentang Administrasi Perkara dan Persidangan di Pengadilan Secara Elektronik. Hasil penelitian menunjukkan bahwa penerapan E-Litigasi pada PTUN dilaksanakan secara menyeluruh, yaitu sejak tahap pendaftaran sampai pada saat pembacaan putusan hakim. Kendala yang masih dihadapi adalah terkait dengan tahapan pembuktian yang pada pelaksanaanya masih membutuhkan sidang konvensional, dan terbatasnya akses jaringan internet di beberapa daerah di Indonesia.

Kata kunci : Persidangan Elektronik; Peradilan Tata Usaha Negara
\end{abstract}

\begin{abstract}
The State Administrative Judicial as the executor of judicial power has a duty and authority to examine, decide, and resolve State Administrative disputes. Along with tecnological development, judicial practices within the scope of the Indonesian Supreme Court hal implemented the ecourt application. The aims of this study is to analyze policies regarding the implementation of Electronic Litigation in the State Administrative Judicial, as well as to find the obstacles encountered. This study uses a normative method with a statute approach, that is Act 5 in 1986 concerning State Administrative Judicial and its amendment, and Supreme Court Regulation Number 1 of 2019 concerning Administration of Cases and Trials in Court Electonically. The result of the study show that the application of Electronic Litigation at State Administrative Judicial is carried out comprehensively, that is from the registration stage until reading of judicial decisions. The obstacles that still being faced are related to the stage of evidence which in practice still requires a conventional trial, and the limited access to the internet network in several regions in Indonesia.

Keywords : Electronic Litigation; State Administrative Judicial
\end{abstract}

\section{Pendahuluan}

Kekuasaan kehakiman merupakan kekuasaan yang merdeka untuk menyelenggarakan peradilan guna menegakkan hukum dan keadilan maka untuk maksud tersebut selanjutnya kekuasaan kehakiman dilakukan oleh sebuah Mahkamah Agung dan badan peradilan yang berada dibawahnya dalam lingkungan peradilan umum, lingkungan peradilan agama, lingkungan peradilan militer, lingkungan peradilan tata usaha negara, dan oleh sebuah Mahakamah Konstitusi. Berbeda dengan tiga lingkungan peradilan lainnya yang berada dibawah wilayah lingkungan kekuasaan Mahkamah Agung, Peradilan Tata Usaha Negara (PTUN) 
hadir guna menyelenggarakan kekuasaan kehakiman dalam rangka menangani suatu perkara yang dipandang sebagai suatu sengketa tata usaha negara termasuk permohonan-permohonan yang terkait dengan lingkup kewenangan mengadili oleh peradilan tata usaha negara.

Setiap sengketa yang disidangkan di Peradilan Tata Usaha Negara dilakukan secara langsung oleh para pihak yang berperkara mulai dari pendaftaran sampai pada sidang putusan hakim, tetapi dalam perkembangannya praktik beracara dipengadilan mulai bergeser mengikuti kemajuan teknologi dan perubahan perilaku masyarakat yang semakin modern memaksa setiap institusi penegakan hukum untuk dapat menyesuaikan kondisi itu, sehingga Mahkamah Agung RI melalui PERMA Nomor Nomor 1 Tahun 2019 tentang Administrasi Perkara dan Persidangan di Pengadilan secara Elektronik mencoba untuk menata secara sederhana dan efisien tata cara teknis berperkara di pengadilan dalam lingkungan Mahkamah Agung dengan media elektronik dalam persidangan (E-Litigasi).

Namun demikian terbatas bagi setiap orang untuk dapat mengakses program elektronik litigasi ini, sebab oleh PERMA Nomor 1 Tahun 2019 tidak secara tegas menempatkan pihak prinsipal sebagai pengguna lainnya. Selain itu, pengguna lainnya yang dimaksud dalam Pasal 1 angka 5 sebelum melakukan pendaftaran tentunya terlebih dahulu memerlukan panduan dan bantuan dari pegawai yang bertugas di pengadilan dalam rangka mengakses program elektronik di persidangan. Lain halnya bagi advokat misalnya, karena program ini justru memberikan kemudahan yang praktis dalam berpraktik apalagi dalam situasi pandemik akhirakhir ini yang membatasi interaksi pergaulan sosial kemasyarakatan demi pencegahan penularan dan penyebaran virus Covid-19 maka sudah semestinya persidangan elektronik menjadi alternatif dan solusi bagi penyelenggaraan kekuasaan kehakiman khususnya dalam lingkungan peradilan tata usaha negara.

Kendala lain yang dihadapi adalah jumlah PTUN yang hanya terbatas pada Kota/Kabupaten tertentu saja. Oleh karena itu, perlu adanya kemudahankemudahan untuk dapat mengakses program elektronik persidangan agar masyarakat tidak harus menjumpai kesulitan dalam rangka mencari keadilan yang ditempuh melalui peradilan tata usaha negara. Dengan adanya sistem E-Litigasi diharapkan dapat lebih mengefisienkan jalannya persidangan.

\section{Metode}

Penulisan artikel ini menggunakan metode penelitian hukum dengan pendekatan yuridis normatif yang mengacu pada ketentuan peraturan perundangundangan yang terkait dengan judul ini. Adapun data yang dipergunakan dalam penulisan ini adalah data sekunder berupa bahan hukum primer diantaranya Undang-Undang Nomor 5 Tahun 1986 tentang Peradilan Tata Usaha Negara dan perubahan-perubahannya serta Peraturan Mahkamah Agung (PERMA) Nomor 1 
Tahun 2019 tentang Administrasi Perkara dan Persidangan di Pengadilan Secara Elektronik, dan bahan hukum sekunder diantaranya literatur berupa buku, jurnal, dan artikel terkait. Penulis menggunakan metode analisis kualitatif preskriptif menurut ketentuan norma hukum yang berlaku dan mendeskripsikan keadaan dengan didukung oleh teori-teori yang relevan dalam pembahasan ini.

\section{Peradilan Tata Usaha Negara Sebagai Pelaksana Kekuasaan Kehakiman}

Peradilan Tata Usaha Negara dibentuk pada rezim Orde Baru lima tahun setelah diundangkannya Undang-Undang Nomor 5 Tahun 1986 tentang Peradilan Tata Usaha Negara berdasarkan Keputusan Presiden Nomor 52 Tahun 1990 tentang Pembentukan Pengadilan Tata Usaha Negara Yang Berkedudukan di Jakarta, Medan, Palembang, Surabaya, dan Ujung Pandang, dan pembentukan PTTUN Jakarta, Medan, dan Ujung pandang Berdasarkan Keputusan Presiden Nomor 10 tahun 19901. Namun demikian jauh sebelum era Orde Baru, eksistensi PTUN telah nampak dalam konstitusi maupun berbagai peraturan-peraturan hukum yang berlaku, termasuk wacana tentang pembentukan PTUN yang dituangkan dalam TAP MPRS RI Nomor II/MPRS/1960 yang memerintahkan agar segera diadakan suatu Peradilan Administrasi Negara², maka pada tahun 1960 oleh Lembaga Pembinaan Hukum Nasional menyusun suatu naskah Rancangan Undang-Undang tentang Peradilan Administrasi Negara ${ }^{3}$.

PTUN adalah salah satu pelaksana kekuasaan kehakiman bagi rakyat pencari keadilan terhadap sengketa Tata Usaha Negara, sebagai lembaga yang menjalankan kekuasaan kehakiman PTUN mempunyai tugas dan wewenang untuk memeriksa, memutus, dan menyelesaikan sengketa Tata Usaha Negara (TUN). Sementara itu, yang dimaksud dengan sengketa TUN adalah sengketa yang timbul dalam bidang tata usaha negara antara orang atau badan hukum perdata dengan badan atau pejabat tata usaha negara, baik di pusat maupun di daerah, sebagai akibat dikeluarkannya keputusan tata usaha negara, termasuk sengketa kepegawaian berdasarkan peraturan perundang-undangan yang berlaku.

Dari ketentuan Undang-Undang PTUN jelas mendudukkan posisi para pihak yang bersengketa antara orang atau badan hukum perdata dengan pejabat TUN sebagai subjeknya. Bahkan dalam sengketa kepegawaian di lingkungan administrasi negara secara internal menjadi lingkup kewenangan mengadili oleh PTUN setelah terlebih dahulu menempuh upaya penyelesaian secara administratif apabila upaya itu telah ditetapkan sebelumnya menurut Undang-Undang. Sementara itu,

\footnotetext{
${ }^{1}$ Zairin Harahap, (2015), Hukum Acara Peradilan Tata Usaha Negara, Rajawali Pers, Jakarta, hal. 28

${ }^{2}$ Administrasi Negara oleh Belinfante diartikan sebagai fungsi pemerintahan yaitu fungsi penguasa yang tidak termasuk pembentukan UU dan Peradilan. Lihat Philipus M. Hadjon dalam bukunya yang berjudul Pengantar Hukum Administrasi Indonesia Introduction to the Indonesian Administrative Law, Gajah Mada University Press, Yogyakarta, hal. 4-3

${ }^{3}$ S.F. Marbun, (2003), Peradilan Tata Usaha Negara, Liberty, Yogyakarta, hal. 8-9
} 
Keputusan Tata Usaha Negara (KTUN) yang memenuhi persyaratan UndangUndang untuk dapat diperkarakan di PTUN adalah merupakan objek dalam sengketa TUN di PTUN.

Terdapat dua alasan utama terbentuknya PTUN berdasarkan penjelasan yang termuat dalam UUPTUN antara lain sebagai berikut4:

a. Ditujukan untuk memberikan perlindungan kepada hak-hak perorangan sekaligus hak masyarakat atas tindakan sewenang-wenang penguasa yang merugikan kepantingan warga.

b. Untuk pemerintah, wajib secara terus menerus membina, menyempurnakan dan menertibkan aparatur di bidang Tata Usaha Negara agar mampu menjadi alat yang efisien, efektif, bersih, dan berwibawa, serta dalam melaksanakan tugasnya selalu berdasarkan hukum dengan dilandasi semangat dan sikap pengabdian kepada masyarakat sehingga tercipta aparatur pemerintahan yang bersih, efisien, efektif, dan berwibawa.

Disamping itu, beberapa ahli diantaranya Riawan Tjandra berpandangan bahwa PTUN dihadirkan guna menyelesaikan sengketa antara pemerintah dan warga negaranya, yakni sengketa yang timbul akibat adanya tindakan-tindakan pemerintah yang dianggap melanggar hak warga negara. Oleh karena itu tujuan pembentukan PTUN yakni ${ }^{5}$ :

a. Memberikan perlindungan terhadap hak-hak rakyat yang bersumber dari hak-hak individu.

b. Memberikan perlindungan terhadap hak-hak masyarakat yang didasarkan kepada kepentingan bersama dari individu yang hidup dalam masyarakat.

Demikian halnya menurut Prayudi Admosudirjo merumuskan bahwa tujuan PTUN adalah untuk mengembangkan dan memelihara administrasi negara yang tepat menurut hukum (rechtmatig) atau tepat menurut Undang-Undang (wetmatig) dan atau tepat secara fungsionil (efektif) dan atau berfungsi secara efisien. ${ }^{6}$ Dapat dikatakan bahwa tujuan dibentuknya PTUN sebagai pelaksana daripada kekuasaan kehakiman merupakan suatu lembaga peradilan yang eksistensinya hadir guna melindungi hak-hak rakyat atas perbuatan kesewenang-wenangan pemerintah serta mengontrol tindakan pemerintah yang menyimpang dari amanah konstitusi maupun perintah Undang-Undang, semata-mata untuk memelihara kewibawaan administrasi negara itu sendiri.

\section{Layanan Berbasis Aplikasi E-Court Sebagai Sarana Administrasi Perkara dan Perdingan Secara Elektronik di Pengadilan}

\footnotetext{
${ }^{4}$ Yuslim, (2016), Hukum Acara Peradilan Tata Usaha Negara, Sinar Grafika, Jakarta, hal. 19

5 Ibid hal. 19-20

${ }^{6}$ S.F. Marbun, Op.cit. hal. 37-38
} 
Dalam berbagai literatur hukum acara dikenal suatu asas bahwa peradilan dilakukan dengan sederhana, cepat dan biaya ringan. Sederhana bermakna tidak berbelit-belit dan mudah memahami hukum acaranya, apabila hukum acaranya mudah dipahami maka peradilan akan berjalan dalam waktu yang relatif cepat, sehingga biaya berperkara juga menjadi ringan ${ }^{7}$. Berangkat dari asas itulah kemudian menjadi salah satu pertimbangan mengapa sehingga perlu dilakukan pembaharuan administrasi dan persidangan guna mengatasi kendala dan hambatan dalam proses penyelenggaraan peradilan, demikian pula termasuk tuntutan perkembangan zaman yang mengharuskan agar pelayanan administrasi perkara dan persidangan di pengadilan lebih efektif dan efisien. Itulah mengapa kedua pertimbangan tersebut sangat kuat untuk menjadi alasan diundangkannya Peraturan Mahkamah Agung Republik Indonesia Nomor 1 Tahun 2019 tentang Administrasi Perkara dan Persidangan di Pengadilan Secara Elektronik.

Seluruh sistem informasi yang berkenaan dengan pemberian pelayanan bagi para pencari keadilan mulai dari administrasi pelayanan perkara sampai pada persidangan elektronik dikenal dengan istilah Sistem Informasi Pengadilan (SIP). Keberadaan pelayaan semacam ini dimaksudkan guna mendukung terwujudnya tertib penanganan perkara yang profesional, trasparan, akuntabel, efisien dan modern. Persidangan secara elektronik atau dikenal dengan istilah E-Litigasi ini berlaku bagi semua jenis perkara baik perkara perdata, perdata agama, tata usaha militer, dan tata usaha negara meliputi seluruh jenjang tingkat peradilan asal dengan ketentuan administrasi perkara tersebut sudah dilaksanakan secara elektronik di tingkat pertama yang mana terlebih dahulu telah disetujui oleh para pihak yang berperkara.

E-Litigasi berlaku untuk proses persidangan dengan acara penyampaian gugatan permohonan, keberatan, bantahan, perlawanan, intervensi beserta perubahannya, jawaban, replik, duplik, pembuktian, kesimpulan dan putusan atau penetapan hakim. Bahkan persidangan dapat dilaksanakan tanpa tatap muka secara konvensional antara hakim, para pihak, panitera pengganti, bahkan pemeriksaan saksi dan ahli pun jika disepakati dapat dilakukan pemeriksaan secara virtual melalui media audiovisual. ${ }^{8}$ Dalam layanan yang berbasis teknologi elektronik ini oleh Mahkamah Agung telah mengejawantahkan hal-hal yang telah diuraikan diatas. Terdapat beberapa sub aplikasi meliputi: 9

a. e-Filing (pendaftaran Perkara Online di Pengadilan)

Pengguna aplikasi e-court merupakan pihak yang mendaftarkan perkara secara online di pengadilan. Pengertian yang dituangkan dalam PERMA No. 1 Tahun 2019 terhadap pengguna aplikasi e-court meliputi pertama sebagai pengguna

\footnotetext{
${ }^{7}$ Zairin Harahap, Op.cit. hal. 25

${ }^{8}$ Muhammad Noor Halim Perdana Kusuma, (2020), Panduan Beracara di Peradilan Tata Usaha Negara dan Persidangan Elektronik (E-Litigasi), KENCANA, Jakarta, hal. 94

${ }^{9}$ https://ecourt.mahkamahagung.go.id
} 
terdaftar dan kedua disebut sebagai pengguna lain. Pengguna terdaftar merupakan advokat yang namanya telah terdaftar di Mahkamah Agung, mempunyai akun e-court dengan terlebih dahulu telah melalui mekanisme validasi advokat oleh pengadilan tinggi tempat dimana advokat disumpah. Sedangkan pengguna lain dimaksud adalah pengguna lainnya selain advokat antara lain jaksa pengacara negara, Biro Hukum Pemerintah/TNI/POLRI, Kejaksaan RI, Direksi/Pengurus atau karyawan yang ditunjuk badan hukum (inhouse lawyer), kuasa insidentil yang ditentukan Undang-Undang. Bagi pengguna terdaftar dapat menggunakan satu akun untuk medaftar berbagai jenis perkara, sementara pengguna lain selain advokat diberikan satu akun yang hanya dapat digunakan untuk satu perkara, selain itu pengguna lain non advokat dapat meminta bantuan kepada petugas bantuan teknis layanan e-court yang ada di pengadilan untuk membuat akun bagi perkara yang akan didaftar. ${ }^{10}$

b. e-Payment (Pembayaran Panjar Biaya Perkara Online)

Setelah pengguna melalui tahap pengimputan pendaftaran online maka pendaftar secara otomatis mendapatkan taksiran panjar biaya elektronik Surat Kuasa Umum Untuk Membayar (e-SKUM) dan nomor pembayaran Virtual Account (VA). Pembayaran dapat dilakukan melalui ATM, SMS bangking atau e-banking kepada akun VA yang ditunjuk setelah mendapat e-SKUM. Setelah pengguna memberikan pembayaran sesuai dengan taksiran panjar biaya e-SKUM, selanjutnya pengadilan memberikan nomor perkara pada hari dan jam kerja, lalu melalui aplikasi e-court akan disampaikan pemberitahuan bahwa perkara sudah terdaftar dipengadilan. Apabila terdapat kekurangan pembayaran dalam penanganan perkara maka tagihan akan disampaikan melalui VA sebaliknya jika diakhir ditemukan sisa panjar biaya perkara maka pengguna akan diberikan penyampaian secara elektronik setelah jurnal keuangan Sistem Informasi Penelusuran Perkara (SIPP) ditutup. ${ }^{11}$

c. e-Summons (Pemanggilan pihak secara online)

Informasi terkait dengan panggilan sidang dan putusan disampaikan kepada para pihak melalui aplikasi ini danatau alamat email yang telah didaftarkan sebelumnya. Namun pemanggilan tidak dapat dilakukan misalnya apabila tergugat belum mendaftarkan alamat emailnya sebagai domisili elektronik atau untuk panggilan pihak ketiga yang hendak diberitahukan haknya untuk dapat menjadi pihak dalam sengketa yang sedang berjalan. Dalam keadaan ini maka pemanggilan secara manual akan dilakukan sampai pihak tersebut hadir dan mendaftarkan alamat emailnya sebagai domisili elektronik. ${ }^{12}$ Adapun syarat sah pemanggilan tetap memperhatikan dan berpedoman pada Pasal 64 ayat (1) dan

\footnotetext{
${ }^{10}$ Muhammad Noor Halim Perdana Kusuma, Loc.cit. hlm 94-95

11 ibid

12 Ibid, hlm 106
} 
(2), Pasal 65, dan Pasal 66 ayat (1), (2), dan (3) Undang-Undang Nomor 5 Tahun 1986 tentang Peradilan Tata Usaha Negara.

d. e-Litigation (Persidangan secara online)

Persidangan secara online akan dilaksanakan apabila semua persyara tan administrasi perkara sudah dipenuhi maka persidangan dapat dilanjutkan secara online mulai dari sidang gugatan sampai pada saat pembacaan putusan hakim. Sebelumnya telah diketengahkan bahwa dalam sistem e-litigasi persidangan dapat dilaksanakan tanpa tatap muka secara konvensional antara hakim, para pihak, panitera pengganti, bahkan pemeriksa saksi dan ahli pun jika disepakati dapat dilakukan pemeriksaan secara virtual melalui media audiovisual.

\section{Persidangan Elektronik Dalam Lingkungan Peradilan Tata Usaha Negara}

Acara persidangan dalam teori hukum acara PTUN pada umumnya terbagi dalam tiga bagian penting, yaitu Pertama meliputi acara biasa; Kedua, meliputi acara cepat; dan Ketiga meliputi pemeriksaan dengan acara singkat. ${ }^{13}$ Masing-masing acara mempunyai karakteristik tersendiri, tentunya selain daripada meteri yang diajukan untuk disidangkan tata cara dan waktu penyelesaiannyapun berbeda. Hukum acara biasa diatur dalam Pasal 68 Undang-Undang PTUN dan seterusnya. Adapun tahapan acara persidangan dilakukan secara lengkap antara lain meliputi pendaftaran gugatan, penelitian administratif, dismissal prosedur/rapat permusyawaratan, pemeriksaan persiapan, pembacaan gugatan, jawaban, replik dari penggugat, duplik dari tergugat, pembuktian, kesimpulan, putusan dalam acara biasa. ${ }^{14}$ Sedangkan pemeriksaan dengan acara cepat memiliki persamaan dan perbedaan dengan acara biasa.

Persamaannya yakni hakim dalam sidang acara biasa dan acara cepat memeriksa dan menguji pokok perkara dan mengakhiri sengketa, sementara yang membedakan diantara keduanya ialah acara cepat diatur dalam Pasal 98 dan Pasal 99 UndangUndang PTUN, sidang dengan acara cepat dapat dilakukan apabila terdapat alasan kepentingan penggugat yang cukup mendesak yakni apabila kepentingan itu menyangkut KTUN yang berisikan misalnya perintah pembongkaran bangunan atau rumah yang ditempati penggugat. Selain itu, waktu pemeriksaan dan putusannya pun dipercepat, di mana tenggang waktu untuk jawaban dan pembuktian bagi kedua belah pihak masing-masing ditentukan tidak melebihi empat belas hari. Berbeda dengan acara biasa hakim yang menangani sengketa dalam acara cepat hanya satu orang atau hakim tunggal semata dan tanpa adanya acara pemeriksaan persiapan maupun replik dan duplik. Disamping itu, mengenai pemeriksaan dengan acara singkat diatur dalam Pasal 62 ayat (4) berkenaan dengan perlawanan atas penetapan ketua pengadilan yang tidak menerima gugatan dalam rapat permusyawaratan

\footnotetext{
${ }^{13}$ Philipus M Hadjon, Op.cit. hlm 331

${ }^{14}$ Muhammad Noor Halim Perdana Kusuma, Op.cit. hlm 101-102
} 
sehingga bagi pihak yang merasa keberatan dapat mengajukan permohonan untuk diperiksa dalam acara singkat namun bukan untuk menyelesaikan pokok sengketa melainkan memberikan penetapan atas permohonan yang diajukan (pengadilan voluntair).

Setelah melalui tahapan pendaftaran sebagaimana yang telah diterangkan sebelumnya maka bagi para para pencari keadilan yang mengajukan tuntutan hak atau gugatan secara elektronik di PTUN wajib memperhatikan persyaratan yang telah ditentukan dalam Pasal 53 Undang-Undang Nomor 9 Tahun 2009 jo Pasal 56 UndangUndang Nomor 5 Tahun 1986 sebab dalam gugatan yang dipersengketakan tentu diantaranya wajib memuat tuntutan hukum (petitum) agar KTUN yang dianggap merugikan kepentingan penggugat itu dapat dibatalkan oleh putusan hakim. ${ }^{15}$ Sehubungan dengan identitas dalam gugatan demikian halnya dengan jawaban dari tergugat perlu dicantumkan alamat email penggugat atau kuasanya sebagai domisili elektronik dalam akun e-court. Hal ini dimaksudkan untuk mempermudah penyampaian informasi pengadilan yang disampaikan kepada penggugat atau tergugat maupun pemohon terkait dengan perkara yang diajukan, dimana pemberitahuan itu nantinya akan dialamatkan melalui email yang telah dicantumkan sebelumnya atau melalui akun e-court.

Selanjutnya oleh kepaniteraan melakukan penelitian administratif terhadap naskah gugatan perihal syarat formil gugatan. Langkah berikutnya dilakukan rapat permusyawaratan atau prosedur dismissal yang juga merupakan karakteristik dalam hukum acara peradilan tata usaha negara yang dilaksanakan oleh ketua pengadilan TUN untuk memberikan suatu penetapan bahwa gugatan tidak diterima atau tidak berdasar sebagaimana yang dimaksud dalam Pasal 62 ayat (1) huruf a, b, c, d, e jo. angka II SEMA Nomor 2 Tahun 1991 bahwa apabila gugatan dinyatakan tidak diterina (nietonvankelijke verklark) maka pihak yang berkeberatan dapat mengajukan perlawanan untuk kemudian dilakukan pemeriksaan melalui sidang dengan acara singkat. Jika berkas gugatan telah melewati kedua tahapan diatas maka dilakukanlah pemanggilan kepada para pihak yang berperkara untuk berikutnya acara dilangsungkan dengan pemeriksaan persiapan (dalam acara biasa), pemberitahuan tersebut disampaikan melalui alamat email yang telah dicantumkan dalam identitas penggugat, akan tetapi bila tidak terdapat atau belum ada alamat email dari pihak tergugat atau pihak lainnya yang ditarik sebagai pihak dalam perkara tersebut maka selanjutnya pemanggilan dilakukan dengan cara manual kealamat domisisli yang tercantum dalam surat gugatan.

Pada intinya bahwa dalam pemeriksaan persiapan di PTUN bertujuan untuk lebih mematangkan perkara, agar pihak penggugat dapat menyempurnakan gugatannya maupun tergugat untuk dimintai keterangannya tentang keputusan yang digugat. Bagi penggugat diberi kesempatan sampai batas waktu 30 hari untuk

${ }^{15}$ Sudikno Mertokusumo, (2009), Hukum Acara Perdata Indonesia, Liberty, Yogyakarta, hal. 53 
melengkapi gugatannya sesuai dengan nasihat hakim. Bilamana gugatan telah disempurnakan, maka penggugat wajib menyampaikan gugatan yang telah disempurnakan dengan cara mengunggah berkas kedalam aplikasi e-court. Ketika gugatan masih belum diperbaiki atau melewati batas waktu perbaikan yang telah ditentukan dalam Undang-Undang PTUN maka konsekuensinya adalah gugatan tidak dapat diterima. Untuk hal yang demikian penggugat tidak dapat mengajukan perlawanan melainkan mengajukan ulang gugatan yang baru sesuai dengan batas waktu yang telah ditentukan dalam Undang-Undang PTUN. Sebaliknya gugatan yang sudah lengkap dan sempurna kemudian selanjutnya layak untuk disidangkan, untuk itu maka ketua majelis hakim akan membuat jadwal persidangan (court calendar) berupa penetapan hari sidang dengan agenda gugatan, jawaban, replik, dan duplik. ${ }^{16}$

Dokumen elektronik berupa gugatan, jawaban, replik, duplik yang sudah ditandatangani diunggah ke persidangan dalam aplikasi e-court sebelum waktu yang telah ditetapkan dalam court calendar. Jika pihak tidak mengunggah dokumen pada waktu yang sudah ditetapkan maka berdasarkan Pasal 22 ayat (4) PERMA Nomor 1 Tahun 2019 pihak yang tidak mengunggah dokumen tersebut dianggap tidak menggunakan haknya, kecuali bagi tergugat tidak mengunggah berkas jawaban diantaranya maka berlaku ketentuan Pasal 72 Undang-Undang PTUN dengan pemanggilan berjenjang yakni apabila tahap pemanggilan terhadap pihak tergugat masih tidak diindahkan sekalipun telah disampaikan pemberitahuan kepada badan atau pejabat TUN yang ada diatasnya maka pemeriksaan perkara tetap dilanjutkan tanpa hadirnya pihak tergugat.

Setelah melalui tahapan-tahapan itu, maka berikutnya dilakukan acara pembuktian, terkait dengan pemeriksaan saksi maupun ahli dalam e-litigasi berdasarkan Pasal 24 PERMA Nomor 1 Tahun 2019 sidang dapat dilakukan setelah disepakati untuk dilaksanakan secara virtual melalui media audiovisual tanpa sidang tatap muka ${ }^{17}$. Pada tahap akhir, para pihak masing-masing mengajukan kesimpulan. Apabila sebelum kesimpulan oleh hakim menjatuhkan putusan sela yang meliputi penundaan pelaksanaan kepusan TUN sebagaimana yang dipersyaratkan dalam Pasal 67 ayat (4), maka putusan akan diucapkan secara elektronik bilamana sejak awal sidang dilaksanakan secara e-litigasi demikian pula halnya untuk putusan akhir dilakukan melalui sistem informasi pada aplikasi e-court, berikutnya para pihak akan dikirimkan salinan resmi putusan melalui akun e-courtnya masing-masing, sedangkan publik dapat mengaksesnya melalui direktori putusan dalam website Mahkamah Agung. ${ }^{18}$

\footnotetext{
${ }^{16}$ Muhammad Noor Halim Perdana Kusuma, Op.cit. hal. 109

17 Ibid

$18 \mathrm{lbid}$
} 
Namun demikian, perihal situasi merebaknya pandemik virus Covid-19 menyebabkan diterapkannya Pembatasan Sosial Berskala Besar di tanah air guna mencegah dan memutus mata rantai penularannya yang mana tentunya membatasi pergerakan orang dari satu tempat ke tempat yang lainnya sehingga akses dalam rangka turut serta mengikuti persidangan pun menjadi terbatas. Olehnya itu kebutuhan akan keguanaan media elektronik yang dapat menghubungkan tatap muka antar subjek dari tempat yang berlainan melalui dunia maya, kemudian menjadi sarana kebutuhan primer bagi berbagai kalangan terutama pada lembaga peradilan khususnya. Berdasarkan situasi tersebut, Mahkamah Agung pada tanggal 30 Maret 2020 mengeluarkan surat Nomor 486/Djmt/B/3/2020 perihal Pelaksanaan Persidangan Secara Elektronik dan surat edaran Mahkamah Agung RI Nomor 1 Tahun 2020 tentang pedoman pelaksanaan tugas selama masa pencegahan corona virus disease (covid-19) di lingkungan Mahkamah Agung dan Badan Peradilan dibawahnya.

Diantara PTUN yang menerapkan pedoman tersebut yakni PTUN Banda Aceh yang menggelar sidang secara teleconference pada tanggal 18 Mei 2020 dengan agenda mendengarkan keterangan saksi ahli dari penggugat, pada persidangan lainnya di PTUN Samarinda pada tanggal 13 Mei 2020 dalam perkara No. 17/G/2020/PTUN.SMD menyelenggarakan sidang teleconference dengan agenda sidang pemeriksaan persiapan. Ada pula pemeriksaan saksi ahli dalam perkara Nomor 1/G/LH/2020/PTUN.PTK. yang tidak memungkinkan ahli untuk menghadiri secara langsung proses acara persidangan dikarenakan keberadaan ahli di Jakarta menyulitkan untuk melakukan penerbangan dalam situasi pandemic covid19. Persidangan secara online juga diatur dalam surat edaran Direktorat Jenderal Badan Peradilan Militer dan Tata Usaha Negara Nomor. 205/Djm/SE/4/2020 tentang Pedoman Pelaksanaan Persidangan Secara Teleconfrence.

Meskipun e-litigasi dapat dilaksanakan, tidak berarti persidangan secara virtual khusunya mengenai pemeriksaan alat bukti dapat berjalan dengan sepenuhnya sebab masih ditemukan beberapa kendala diantaranya dalam hal hakim saat mengautentifikasi alat bukti surat harus melihat keputusan asli yang ditandatangani secara manual, sidang konvensional tetap digelar. ${ }^{19}$ Selain itu kekuatan jangkauan signal menjadi penentu jalannya persidangan secara online terutama bagi masyarakat yang berada di daerah yang masih belum dapat menjangkau signal telekomunikasi atau internet tentu akan mengalami hambatan untuk dapat mengikuti jalannya persidangan.

\section{Penutup}

Peradilan Tata Usaha Negara sebagai pelaksana kekuasaan kehakiman mempunyai tugas dan wewenang untuk memeriksa, memutus, dan menyelesaikan

\footnotetext{
${ }^{19}$ Muhammad Noor Halim Perdana Kusuma, Op.cit. hal. 114
} 
sengketa Tata Usaha Negara (TUN), dalam perkembangannya pada dasarnya telah memberikan akses pelayanan bagi para pencari keadilan berdasarkan prinsip dalam hukum acara. Salah satunya melalui E-litigasi. Sebagai bentuk pelaksanaannya, Mahkamah Agung telah membuat aplikasi yang dinamakan e-Court Mahkamah Agung RI sebagai bentuk layanan yang berbasis teknologi elektronik. Adapun penerapan E-litigasi sangat tepat dilakukan pada masa pandemi saat ini secara efektif dan efisien. Namun, masih terdapat beberapa kendala dalam pelaksanaan E-litigasi, baik yang terkait pelaksanaan dan tahapan sidang, maupun teknis penerapan sidang, seperti akses jaringan internet yang terdapat di setiap wilayah di Indonesia.

\section{REFERENSI}

Muhammad Noor Halim Perdana Kusuma, Muhammad Adiguna Bimasakti, (2020), Panduan Beracara di Peradilan Tata Usaha Negara dan Persidangan Elektronik (ELitigasi), Jakarta: Kencana.

Philipus M. Hadjon dkk, (2008), Hukum Administrasi Indonesia Introduction to the Indonesian Administrative Law, Yogyakarta: Gajah Mada University Press.

Ridwan HR, (2011), Hukum Administrasi Negara, Jakarta: Rajawali Pers.

SF Marbun, (2003), Peradilan Tata Usaha Negara, Yogyakarta: Liberty.

Sudikno Mertokusumo, (2009), Hukum Acara Perdata Indonesia, Yogyakarta: Liberty.

Yuslim, (2016), Hukum Acara Peradilan Tata Usaha Negara, Jakarta: Sinar Grafika.

Zairin Harahap, (2015), Hukum Acara Peradilan Tata Usaha Negara, Jakarta: Rajawali Pers.

https://ecourt.mahkamahagung.go.id 